\title{
Clinical Sociology and Moral Hegemony
}

\author{
Hans Petter Sand \\ University of Agder, Kristiansand, Norway \\ Email: hans.p.sand@uia.no
}

Received August 26 ${ }^{\text {th }}$, 2013; revised September 26 $6^{\text {th }}$, 2013; accepted October $3^{\text {rd }}, 2013$

\begin{abstract}
Copyright (c) 2013 Hans Petter Sand. This is an open access article distributed under the Creative Commons Attribution License, which permits unrestricted use, distribution, and reproduction in any medium, provided the original work is properly cited.
\end{abstract}

\begin{abstract}
The article presents a critique of a dominant way of analysing gang conflict in Norwegian sociology. The research in question uses a rather crude Marxist analysis that could somehow fit any gang conflict in the country. However, this kind of analysis was gradually put in question first by professor Ottar Brox and his criticism of the moral hegemony by a group of Marxists gathered around the publication "Klassekampen" ("Class Struggle"). Then the analysis was challenged by gang-researchers who reached back to the classical study of Frederic M. Thrasher, finding the latter more fruitful for analysis. Antonio Gramsci (18911937) who coined the term cultural hegemony used it to describe how a social class can manipulate the system of values in a society to establish a ruling class world-view. In my context the term moral hegemony is used to show how an intellectual group came to dominate the discourse on relations between Norwegians and immigrants, labelling other views as "racist".
\end{abstract}

Keywords: Gangs; Marxist Framework; Moral Hegemony; Contested; Frederic M. Thrasher

\section{Thrasher's Classical Study}

Thrasher (1927) pointed to that gangs in Chicago were primarily a phenomenon of the children of foreign-born immigrants. The child of the immigrants tends to escape the control of parents, school, church and voluntary associations. The gang arises as a sort of substitute group. It becomes a substitute for the belonging to and identification with other groups.

To Thrasher the gang often grows out of play groups of boys. When play groups encounter the forces and agencies of control, they may soon develop a "we" feeling, and the process of forming a gang may begin. The ganging process is a continuous flux and flow, and there is little permanence in most of the gangs.

Thrasher maintains that gangs grow out of needs the boys have and which are not met by society. The boys get thrill and zest from participating in common action; hunting, capture, flight and escape. Conflict with other gangs gives rise to many exciting activities.

Thrasher puts great emphasis on gang warfare. The gang is a conflict group. It develops through strife and thrives on warfare. The members of a gang will fight each other. They will even fight for a "cause", almost with no regard for what the cause may be.

A gang struggles for existence by fighting competing groups to protect its territory and its members. It attempts to maintain its status among other gangs by trying to get a reputation for being tough in fights.

The gangs see life as a struggle and this fact explains a lot of gang behaviour and the relation of gangs to society. It may be tempting for an outside observer to see the struggle as a pecularity, but seen from within, this is the hearing of the matter.

\section{A Marxist Analysis}

Since around 1990 there has been a substantial increase in gang research in Norway. This has to do with the increase in gangs of young immigrants fighting among themselves and even more, fighting with Norwegian gangs. These phenomena seem to be very much like the ones Thrasher described and analyzed in his classical study. However, the phenomena were initially to a large extent interpreted within a framework of racism and anti-racism, which is a dominant discourse in Norwegian society. This discourse was inspired by Marxist sociology, seeing immigrants as suppressed by society, and the fighting of gangs as a result of this suppression.

However, I will here show how this dominant discourse became contested, and thus the analysis of Thrasher became more dominant in gang research.

The first of the studies I will review, from the end of the 1990s until today, is a study by criminologist Guri Larsen (1992) called Brodre. Aereskamp og hjemloshet blant innvandringens ungdom ("Brothers. Fight for Honor and Homelessness among Immigrant Youngsters"). The study deals with fighting between two gangs from the same immigrant minority, which ended in a killing of one of the gang-members, and a subsequent lawsuit.

Under the title of Racism a key informant tells Larsen that in his home country there was no racism, probably because there were people of many races.

But in Norway he was being bullied, he said. One of his best friend started to call him "bloody blackie".

A gang of Norwegians used to beat foreigners in the informant's schoolyard. They even attacked an immigrant boy who was standing alone in the schoolyard eating his food. He was beaten until he womited blood.

Aften this incident, the informant and two of his friends attacked the gang of young Norwegians who had beaten immigrant youngsters.

The informant also tells that he hated the Norwegians who bullied him and his friends. This also led him to quit school. He 
could not stand the school because of all the bullying.

Then he and his friends were trained in martial art to protect themselves. He felt very proud that he had a good command of martial art.

He explicitly talks about the racists, implying that there are a lot of them in Norway. The racists tell lies about immigrant, they make people believe that all immigrants are criminals and make problems for Norwegians. The racists maintain that the immigrants spoil the social climate in Norway. The informant argues that the police make people become racists.

He also tells about actual and planned fightings with young Norwegians identified as racists.

The study describes how the boys in the two gangs who ended up in a fight that killed one on the gang members, used to be friends, even feel like brothers, because they came from the same country. They used to share most things, they always stuck together, protected and helped each other. But at a time they split up into two gangs who became bitter enemies. There was a lot of fighting between them up to the moment when one of the gang members was killed.

Larsen tells about the different interpretations of what went on in the time of the fightings that led up to a murder, a trial and conviction of some of the youngsters. She maintains that the ways of interpretation can be separated into two main categories: Other people's interpretations (press, court) and the understanding of the youngsters themselves.

Other people's interpretations are connected to the fact that the conflicts between the youngsters have become a judicial concern. The youngsters appear first and foremost only as accused and perpetrators. Two different pictures are depicted in the interpretations that emerge: The responsible man of violence and the victim of structural relations.

The youngsters object to the interpretations of the others, they see the violence between them as a fight for honor.

It seems like Larsen rounds up her analysis with structural suppression as the explanation:

"It is no news that suppressed groups direct the blows against each other when anger and despair of discrimination and exclusion from society become too much. Fighting and relentlessness between youth is part of a well known pattern. Blacks in the slums of great cities in the USA, Western Europe and South Africa, groups of indigenous people and other youngsters without strong basis in society, do the same. But people react to suppression in different ways. Only a few end up with use of violence" (Larsen, 1992: p. 127, my translation).

The choice of this more Marxist inspired analysis has probably to do with the author being employed at the Institute of Criminology at the University of Oslo. The institute has a long history of being partisan for underprivileged groups and with a Marxist theoretical outlook.

This is emphasized by the information on the back-cover of the book:

"Guri Larsen (b. 1943) is educated as a criminologist, working at the Institute of Criminology at the University of Oslo. She has for several years been working with immigration problems, and has participated actively in the public debate and anti-racist work (my underlining, my translation)”.

\section{Hegemony of the Moral Elite}

Professor of social science, Ottar Brox (1991), maintains in his book "Jeg er ikke rasism, men..." ("I am nor a Racist, but....” my translation) that a so-called moral elite in Norway got a kind of monopoly in the discourse of racism. Contrary to solid data showing that there were few racists in the Norwegian population, the moral elite argued that there was a lot of racism, and they tended to interpret almost all critical remarks on immigration as racism. The leading newpaper articulating these views, was the Marxist-Leninist newspaper called Klassekampen ("Class-Struggle"). Guri Larsen was one of the central contributors in the debate in this newspaper. Brox writes:

"Since so many of my examples of moralist argumentation is taken from Klassekampen, it could seem obvious to question that I let the writings in this extreme left-wing newspaper be representative of the whole 'moral elite'. Many of those who argue for open borders, or at least more immigration, and more public generousity to those who come, do not write in this newspaper, and they support quite other political parties”.

As I have said before, Klassekampen has not been chosen as a main source from the idea that the newspaper in every respect is representative of the left side.

But I have assumed that in matters of immigration the newspaper builds on, or refers to, a syndrome of honorable values that all of the left side, with its allies in Christian people and bourgeois humanism, have in common. Klassekampen is thus representative when it comes to basis of values...

However, Klassekampen is in no way "representative" in ways of expressing these values, and I use the newspaper as main source from an assumption that it will be on top compared to most others when it comes to finding the strongest possible expression of these common values. In this way it will be in the front in the moral competition of expression in the left field, and exercise a certain "hegemony" in the respect that it can intimidate others in the broader community of values... (Brox, 1991: p. 74, my translation).

\section{Towards Thrasher's Analysis}

A lot of studies on Norwegian gangs were published from 1998 and up to today. The researchers were for the most part working at the Norsk Instititutt for by-og regionalforskning ("Norwegian Institute of Urban and Regional Research"), doing applied research for the government. The researchers describe the situation as follows:

"Norwegian research on gangs consisting of youngsters with a minority background has until recently been relatively sparse. But neo-nazi or racists groups, gangs and groupings have been thoroughly studied by several Norwegian researchers, for instance Bjorgo, 1997, Fangen, 2000, Carlsson and von der Lippe, 1997 and 1999, Bjorgo \& Carlsson, 1999 and Fangen, 2001."

One of the few studies that has been done in this country of violent groups or gangs consisting of youngsters with immigrant background, was done by Guri Larsen, 1992 (see my description of this study earlier in this paper). She described the conflicts between the Pakistani gangs Young Guns and Killers. Lien and Haaland conducted in 1997/98 a pilot study of gangs and gang behavior in Oslo. The study emphasizes the codes of honor and strong alert towards possible offences, and the subsequent spiral of revenge that takes place. Elisabeth Naess (1999) showed how violence and fights bind the gangs together (Bjorgo \& Carlsson, (2001: p. 17, my translation).

With financial support from the Department of Justice a group of researchers at Norsk Institutt for by-og region-forskning and Norsk Utenrikspolitisk Institutt ("Norwegian Institute of Foreign Policy") launched a research project to map and 
analyze the phenomenon of gangs in four larger Norwegian towns. Central problems were: What kind of processes create violent gangs? What processes create the special form of "bonding" that is found in gangs? Are these forms of social bonds special for gangs, or are such structures surrounded by special ways of thinking, norms and values? How are gangs transformed from one stadium to another, from group of friends, to a violent gang, and eventually to a more organized and profit-oriented criminal gang?

It seems to me that these were more or less the same questions Thrasher posed.

The four towns that were chosen for the project were Oslo (the capital of Norway), Drammen, Kristiansand and Stavanger. It turned out that the researchers came to consentrate on Kristiansand and Oslo. In Kristiansand the immigrant gangs were dominated by second generation latin American boys, while in Oslo most gangs were of second generation Pakistanis. Outside Drammen there existed an organized group of Nazis or neonazis who displayed aggressive language against young immigrants. These were studied by Fangen (1995). But while the at that time dominant Marxist analysis emphasized that Norwegian gangs were neo-nazis, in fact the group outside Drammen was the only organized group with a clear ideological view.

The researchers maintain that there may be many and invisible causes that a part of the youngsters with a minority background flock together in groups that become involved in violent and other criminal acts. An especially important such reason is conflict with other youngsters or youth groups. And they quote the man they regard as the pioneer of American gang research, Frederic M. Thrasher, who stated that "The gang is a conflict group. It develops through strife and thrives on warfare". They conclude that later research has shown that this postulate is still valid.

The researchers then go on to discuss gangs and gang violence in a way very similar to Thrasher. They write that immigrant youngsters can enter into gangs consisting of youngsters from only one ethnic group, or in multi-ethnic gangs, were also Norwegian youngsters may participate. The axis of conflict may sometimes go between gangs of the same ethnic origin, which has been the case with the recurring conflicts between Pakistani gangs in Oslo. The conflicts between the gangs Young Guns and Killers and between the A-and B-gang in Oslo are such examples. But the lines of conflict may also go between groups of majority youngsters and groups of minority youngsters. Then the two groups tend to articulate the antagonisms in the form of articulate racist and anti-racist positions and ways of acting. The discussion ends up with a conclusion quite different from the afore mentioned marxist researcher. They write: "But under this seemingly political conflict there is often hidden dimensions of conflict that are about quite different things" (my underlining, my translation).

The patterns that are outlined in several Norwegian towns is that minority youngsters seek together in strong groups and gangs to protect themselves against a perceived threat from racist and neo-nazist groups. At the same time some majority youngsters who have experienced being threatened or robbed by immigrant gangs, will tend to seek together in ethnic Norwegian gangs to protect each other-or already existing racist groups offer them protection.

Some researchers (Eidheim, 1993: p. 17) argues that "racism/ neo-nazism" or "antiracism" are so morally authoritative concepts - and saturated by meaning and associations - that it is easy to loose the ability to analyze and reflect critically around the phenomena that get these labels.

In a similar vein, Katrine Fangen almost feels like asking for excuse for studying so-called neo-nazis:

"The report is meant to be a contribution to the understanding of how the participants think and interact. Such a research approach will for many people be provocative, because such an understanding often will be misunderstood in the direction of 'being sympathetic to' or 'defend'. My point of departure is that a closer knowledge of the life-world of these youngsters is essential in order to grasp the development in a reasonable way" (Fangen, 1995: p. 8, my translation).

She also argues that the concept of gang is more suitable than the concept of subculture when we shall look at definite situations of interaction, both between the nationalists in encounter with their adversaries, and when we shall look at the interaction withing the collective. And she refers explicitly to Thrasher. A gang is, as Frederic M. Thrasher defines it, characterized by that it has a spontaneous, undefined origin. A gang arises when a number of youngsters are present at the same arena, for example that they constantly meet each other on the street corner or the gas station. To constitute a gang, they must in addition meet regularly in face to face situations. The typical gang behavior has a certain playful character. The gang often develops a characteristic humor, a characteristic language and a characteristic way. Its members are out for adventurous experiences that break with a conventional, routine way. Different forms of partying behavior like games, drinking, smoking and picking up girls are typical gang behavior. The goal of the gang members is to have fun together. In encounters with other gangs, however, most gangs will, according to Thrasher, be able to participate in fights and behave as "mob". It is the special organization, solidarity and morale that enables the gang to behave like a ruthless mob with great destructive urge, far beyond what the single member can account for on his own.

Bjorgo and Carlsson discuss in their research report (1999) the distinction between racism as expression and racism as driving force. This shows, in my opinion, that the dominant discourse about racism still had some grip in the Norwegian debate and even in the research community. Hovewer, they argue that when we are dealing with the phenomenon of "racist" violence, it can be useful to go deeper into the division between racism as an expression, and racism as a driving force or motive. Many of those acts that express racism - for instance if a youth gang breaks the windows of a shop run by immigrants and paints swastikas-is run by other motives than racist ideology. For example, it often is about showing yourself for the gang, and to outdo each other in aggressivity and courage, or a wish to get publicity and attention.

And they go on to argue that relatively few of those who exercise racism are motivated first and foremost by a racist conviction and ideology. For those racism is both driving force and expression. For a considerably larger portion it is quite other motives than ideology which is the primary driving force behind their racist acts and expressions. Other who exercise racism have a combination of motives, where racism only make up one element among others.

Racism does not only have connection with "white” youngsters against "black" youngsters, but it can also be an affecting factor in situations where the violence goes the other way. When youngsters with immigrant background seek to violent gangs, this often has to do with the experience of racism, dis- 
crimination and marginalization in Norwegian society. The relations can here be varied and complex. Partly can seeking protection in a violent gang be a reaction to an experienced threat about racist violence, for example from a "white" gang with a nationalist image. Others can feel that they are excluded from work, school etc. because of poor command of the Norwegian language. If such experiences go together, they can give immigrant youngsters a feeling that they have no future within the legal system in Norway. For some youngsters violent gangs then appear as a more attractive alternative. A lot of these immigrant youngsters also use claims about racism as a legitimation of their own use of violence against Norwegian youngsters.

Discussions about the concept of racism tend to focus on what racism really is about. The researchers find it more fruitful to see the concept as a relative and contextual concept. To see the concept as relative means that there are degrees of negative attitudes to a certain category of people, and these can vary from a passive fear of strangers, via a more aggressive hostility towards strangers and finally to and ideologically underpinned racism.

To contexualize the concept of racism is that these different degrees of negative attitudes can come to expression in different social contexts. A gang of youngsters looking for action and excitement is a totally different context than an association of elderly men discussing population policy and immigration.

\section{A Central Monograph of Chicago Sociology}

Frederic M. Thrasher's The Gang. A study of 1313 Gangs in Chicago, is often mentioned together with a number of famous monographs from the so-called "golden era" of Chicago sociology (Dobson, 1962). According to Bulmer (1984) The Polish Peasant in Europe and America, by W. I. Thomas and Florian Znaniecki, published in 1918 - 20, marked the beginning of the flourishing research milieu at the University of Chicago. This milieu was under the leadership of Robert Ezra Park. The end of the era came when Park retired in the early 1930s. Other famous monographs often mentioned are Louis Wirth's The Ghetto, (1928), Harvey Zorbaugh's The Gold Coast and the Slum, 1929, Paul Cressey's The Taxi-Dance Hall, 1932, Nels Anderson's The Hobo, 1923 and Clifford Shaw's The JackRoller, 1930.

The author is under especial obligation to Robert E. Park, editor of this series (University of Chicago Sociological Series, my comment), who read the manuscript and the proofs and who has made many suggestions of great value with reference to the interpretation of the materials and the preparation of the manuscript.

In his introduction to the abridged edition, Short (1963:xv) maintains that Thrasher's work is a "modern classic". First of all, it stands, after several decades (and probably today, my remarks) as the most comprehensive study of gangs of youngsters ever done.

In the so-called Chicago school of sociology the city was a laboratory of study, and Thrasher was one of its pioneers. This was an age of great enthusiasm about discovery in American sociology, and Chicago was its center. The old "Green Bible" (Robert E. Park and Ernest W. Burgess: Introduction to the Science of Sociology, Chicago University Press, 1921) urged the students to observe and record life in every possible setting, and to generalize its forms and processes. This was the essential spirit of the "Chicago School", and it is the spirit of The Gang
(Short, 1963).

\section{The Gang}

Thrasher proposes a definition of the gang, based upon this study:

"The gang is an interstitial group originally formed spontaneously, and then integrated through conflict. It is characterized by the following types of behavior: meeting face to face, milling, movement through space as a unit, conflict and planning. The result of this collective behavior is the development of tradition, unreflective internal structure, esprit de corps, solidarity, morale, group awareness, and attachment to a local territory" (Thrasher, 1963: p. 46).

It seems like the gang meets the demand for types of activity which particularly appeal to the boy. The quest for new experience seems to be especially important for the young boy. In the gang he can get the desired escape from, or compensation for, monotony. The gang activities offer movement and change, games and gambling, stealing, vandalism, sports, imaginative play and drifting around. This stimulates the boy to expect even more excitement. Ordinary business and pleasure seems tame and dull compared with experiences in the gang. This can, according to Thrasher, explain a lot also of the behavior of gangs of gangsters. A youngster or an adult who has become habituated to a life of crime, is defined by Thrasher as a "gangster".

To sum up this discussion, the author states:

"The fundamental fact about the gang is that it finds in the boys who become its members a fund of energy that is undirected, undisciplined, and uncontrolled by any socially desirable pattern, and it gives to that energy an opportunity for expression in the freest, the most spontaneous and elemental manner possible, and at the same time intensifies all the natural impulses by the process of cumulative stimulation" (Thrasher, 1963: p. 83).

Thrasher puts great emphasize on gang warfare. The gang is a conflict group. It develops through strife and thrives on warfare. The members of a gang will fight each other. They will even fight for a "cause", almost with no regard for what the cause may be.

A gang struggles for existence by fighting competing groups to protect its territory and its members. It attempts to maintain its status among other gangs and in the neighbourhood by trying to get a reputation for being tough in fights.

Gangs usually have areas which they regard as their own and where it may be dangerous for other gang members to appear. So gang warfare is usually organized on the basis of territory.

The gangs see life as a struggle and this fact explains a lot of gang behavior and the relation of gangs to society. It may be tempting for an outside observer to see the struggle as a peculiarity, but seen from within, it is the heart of the matter.

In Thrashers's own words:

"The gang, then, to sum up, is one manifestation of the disorganization incident to cultural conflict among diverse nations and races gathered together in one place and themselves in contact with a civilization foreign and largely inimical to them" (Thrasher, 1963: p. 154).

Furthermore, Thrasher observed that the gang in Chicago was primarily a phenomenon of the children of foreign-born immigrants. The child of the immigrants tends to escape parental control and become superficially Americanized. The normally directing institutions of family, school, church, and rec- 
reation break down and the gang arises as a sort of substitute organization.

\section{Conclusion}

In this article I have reviewed the Norwegian research on gangs from around 1990 up to the present. This represents, more or less, all gang researches that have been done in the country.

I have shown that the first research report drew on a Marxist frame of analysis, seeing second generation immigrants as suppressed by society and consequently fighting each other. What is not taken up in this report, because it dealt with gang of young immigrants fighting each other, is that the frame of analysis also sees young Norwegians fighting immigrant youngsters as racists, Nazis of neo-nazis. This frame of reference also became dominant in the public debate over gang problems, with the weekly newspaper Klassekampen as the central proponent of this view. People with other views easily came to be labelled as racists by researchers and activists around Klassekampen. The group of marxists around Klassekampen came to achieve a moral hegemony in the debate over gangs in Norway.

Another problem with this Marxist analysis was, in my view, that the main concepts: suppression, racism, Nazism, neo-nazism were too crude to give a proper insight into the complex problems of gangs and gang-behavior.

Gradually, however, this dominant perspective was contested and refuted. In this process there was a rediscovery of Thrasher's classical analysis. Thrasher's description and analysis is much richer and gives a better insight into the dynamics of gangs of second generation immigrants and their fights among themselves and with gangs of the native population.

\section{REFERENCES ${ }^{*}$}

Anderson, N. (1961). The hobo: The sociology of the homeless man. Chicago.

Brox, O. (1991). Jeg er ikke rasist, men..., Oslo.

Bulmer, M. (1984). Institutionalization, diversity, and the rise of sociological research. Chicago and London: The Chicago School of Sociology.

Bjorgo, T., \& Yngve, C. (1999). Vold, rasisme og ungdomsgjenger. ("Violence, Racism and Youth Gangs"), Oslo.
Bjorgo, T., Yngve, C., \& Thomas, H. (2001). Generalisert hat-Polariserte fellesskap. (“Generalized Hatred-Polarized Communities”), Oslo.

Carlsson, Y., \& Thomas, H. (2004). Voldelige ungdomsgrupper-intervensjon på kommunenivå ("Violent Youth Groups-Intervention on the Local Level"), Oslo.

Coser, L. A. (1977). Masters of sociological thought (Chapters on Robert Ezra Park and William I. Thomas and Florian Znaniecki). New York.

Cressey, P. G. (1968). New York: The taxi-dance hall: A sociological study in commercialized recreation and city life.

Dobson, D. W. (1962). Frederic milton thrasher 1892-1962. American Sociological Review, 27, 580-581.

Fangen, K. (1995). Skinheads i rodt, hvitt og blått ("Skinheads in Red, White and Blue"), Oslo.

Eidheim, F. (1993). Hva har skjedd I Brummundal:Lokalsamfunnet i mote med de fremmede og seg selv ("What has Happened in Brummunddal-the Local Community meeting Strangers and Themselves"), Oslo.

Faris, R. E. (1970). Chicago sociology. 1920 - 1932. Chicago and London.

Frones, I., \& Lise, K. (2003). Det norske samfunn ("Norwegian Society"), Oslo.

Larsen, G. (1992). Brodre. Aereskamp og hjemloshet blant innvandringens ungdom. Oslo.

Thrasher, F. M. (1963). The gang. A study of 1313 gangs in Chicago. Abridged with a new introduction by J. F. Short Jr. Chicago and London.

Sand, H. P. (1997). Ungdom I sentrum ("Youngsters in the City Center”), Kristiansand kommune ('Kristiansand Municipality'), Kristiansand.

Sand, H. P. (2006). Challenges in dealing with different interests between organized and unorganized youth. Journal of Comparative Social Work, 2006/1. Department of Social Sciences, Bodo University College.

Shaw, C. R. (1966). The jack-roller: A delinquent boy’s own story/Chicago.

Smith, D. (1988). The Chicago school. A liberal critique of capitalism. London.

Park, R. E., \& Ernest, B. (1969). Introduction to the science of sociology (3rd ed.). Chicago.

Wirth, L. (1938). The ghetto new brunswick.

Zorbaugh, H. W. (1976). The gold coast and the slum: A sociological study of Chicago's near north side Chicago.

\footnotetext{
*I have tried to translate titles of Norewegian books, articles and institutions into English, either in the text itself or in the reference list, putting it in brackets and quotation marks).
} 